УДК 334.72

Коренюк Петро, доктор економічних наук, професор, завідувач кафедри менеджмента организацій и адміністрування, Дніпровський державний технічний університет, м. Дніпро; e-mail: korenyukp@gmail.com

Усикова Олена, доктор економічних наук, доцент, в.о. директора навчально-наукового інституту економіки та управління, Миколаївський національний аграрний університет, м. Миколаїв, ORCID ID 0000-0001-6734-5757 e-mail: elenamb73@ rambler.ru

https://doi.org/10.29038/2411-4014-2019-04-133-140

\title{
АНАЛІЗ ЕФЕКТИВНОСТІ УПРАВЛІННЯ ПЕРСОНАЛОМ В КОНТЕКСТІ ІНТЕЛЕКТУАЛЬНОЇ ВЛАСНОСТІ
}

Сьогодні всі розуміють, що для того щоб розвиватись, одержувати прибуток і зберегти конкурентоспроможність організації, керівництво повинно оптимізувати віддачу від вкладень будь-яких ресурсів: матеріальних, фінансових і головне - людських. Коли організація дійсно турбується про людей, їі загальна філософія, клімат і настрій обов'язково відбивається на результатах.

Одним із суттєвих показників культури управління являється стиль керівництва. Можна говорити про загальний стиль роботи, який притаманний апарату управління даної організації в цілому, і про індивідуальний стиль, який являється характерним для окремих керівників. Загальний стиль управління складається під впливом переважаючих особливостей стилю окремих керівників. I, навпаки, індивідуальний стиль формується на основі загального стиль управління із урахуванням певних умов роботи та особистих психічних, інтелектуальних та професійних особливостей даного керівника.

Ключові слова: персонал, система управління персоналом, ефективність, удосконалення.

Коренюк Петр, доктор экономических наук, профессор, заведующий кафедрой менеджмента организаций и администрирования, Днепровский государственный технический университет, г. Днипро

Усикова Елена, доктор економических наук, доцент, и.о. директора учебно-научного института скономики и управения Николаевский национальный аграрный университет, г. Николаев

\section{АНАЛИЗ ЭФФЕКТИВНОСТИ УПРАВЛЕНИЯ ПЕРСОНАЛОМ В КОНТЕКСТЕ ИНТЕЛЛЕКТУАЛЬНОЙ СОБСТВЕННОСТИ}

Сегодня все понимают, что для того чтобы развиваться, получать прибыль и сохранить конкурентоспособность организации, руководство должно оптимизировать отдачу от вложений любых ресурсов: материальных, финансовых и главное - человеческих. Когда организация действительно заботится о людях, ее общая философия, климат и настроение обязательно отражается на результатах.

Одним из существенных показателей культуры управления является стиль руководства. Можно говорить об общем стиле работы, который присущ аппарата управления данной организации в целом, и об индивидуальном стиле, который является характерным для отдельных руководителей. Общий стиль управления складывается под влиянием преобладающих особенностей стиля отдельных руководителей. И, наоборот, индивидуальный стиль формируется на основе общего стиль управления с учетом определенных 
условий работы и личных психических, интеллектуальных и профессиональных особенностей данного руководителя.

Ключевые слова: персонал, система управления персоналом, эффективность, совершенствование.

\author{
Korenyuk Peter, \\ Doctor of Economics, Professor, \\ Head of the Department of Management of Organizations and Administration, \\ Dnieper State Technical University, \\ Dnipro city
}

Usykova Elena, Doctor of Economics, Associate Professor, Director of the Educational and Scientific Institute of Economics and Management Nikolaev National Agrarian University, Nikolaev

\title{
PERSONNEL MANAGEMENT EFFICIENCY ANALYSIS IN THE CONTEXT OF INTELLECTUAL PROPERTY
}

Today, everyone understands that in order to develop, make a profit and keep the organization competitive, management must optimize the return on investment of any resources: material, financial, and most importantly human. When an organization really cares about people, its overall philosophy, climate and mood necessarily reflects on the results.

One of the essential indicators of a management culture is leadership style. We can talk about the general style of work, which is inherent in the management apparatus of this organization as a whole, and about the individual style, which is characteristic of individual leaders. The general management style is influenced by the prevailing style features of individual leaders. And, on the contrary, an individual style is formed on the basis of a general management style, taking into account certain working conditions and personal mental, intellectual and professional characteristics of a given leader.

Keywords: personnel, personnel management system, efficiency, improvement.

Постановка проблеми. Управління персоналом є досить складним процесом, який повинен мати завершеність на основі комплексного вирішення кадрових проблем, впровадження нових напрямів в управління й удосконалення існуючих форм, методів роботи. Організація майбутнього (успішними організаціями майбутнього, швидше за все, будуть ті, які можуть рухатися швидше, швидше адаптуватися, швидше вчитися і сприймати динамічні запити до картері). Сьогодні всі розуміють, що для того щоб розвиватись, одержувати прибуток і зберегти конкурентоспроможність організації, керівництво повинно оптимізувати віддачу від вкладень будь-яких ресурсів: матеріальних, фінансових і головне - людських. Коли організація дійсно турбується про людей, піi загальна філософія, клімат і настрій обов'язково відбивається на результатах.

Аналіз досліджень цієї проблеми. Аналіз останніх досліджень і публікацій. Розгляду питань управління персоналом присвячено багато робіт іноземних (С . Адамс, М. Армстронг, В. Врум, А. Маслоу, М. Портер, Т. Стівенс, Ф. Уайтлі, Ф. Херцберг, Е. Мейота та ін.) і вітчизняних вчених (Д. Богиня, О. Бєляєв, В. Воронкова, О. Грішнова, А. Колота, В. Колпаков, О. Левченко, Е. Лібанова, О. Мартякова, Л. Мельник, С. Мочерний, В. Никифоренко, В. Савченко, С. Сіденко, І. Тимошенко, Л. Тимошенко, Л. Шаульська, О. Шилець та ін.) , в яких досліджуються фундаментальні питання управління розвитком людських ресурсів і персоналу. Виділення невирішених раніше частин загальної проблеми. Але, не дивлячись на широке коло проведених досліджень, ряд питань щодо удосконалення стратегічного управління підприємствами

Мета й завдання статті Головною метою статті є вивчення і оцінка ефективності управління персоналом в промиславих підприємствах з метою удосконалення системи управління персоналом .Головна мета системи управління персоналом складається в забезпеченні підприємства працівниками, що відповідають вимогам даного підприємства, їхньої професійної і соціальної 
адаптаціїДля досягнення поставленої мети в роботі було поставлено наступні задачі: проаналізувати теоретичні аспекти системи управління персоналом підприємства; визначити основні підходи до оцінки ефективності управління персоналом тощо.

Виклад осоновного матералу. Поняття управління персоналом досить складне та багатогранне, тому його вивчають та досліджують вчені самих різних наукових напрямків: філософи й соціологи, психологи та фізіологи, статистики й математики, економісти та програмісти. Сутність управління персоналом можна визначити як систему взаємовідносин між суб'єктом і об'єктом управління в площині організаційно-економічних, соціальнопсихологічних та правових питань. Метою управління $є$ збільшення віддачі персоналу в ході вирішення виробничих завдань для максимально ефективного забезпечення цілей організації, за рахунок застосування сукупності принципів, методів і форм впливу на працівників. Не зважаючи на те, що працю розглядають як виробничий ресурс поряд 3 іншими факторами виробництва, її не можна ототожнювати з ними.

Головні відмінні риси постіндустріального суспільства від індустріального - досить висока продуктивність праці, висока якість життя, сектор інноваційної економіки, що переважає, 3 високими технологіями і венчурним бізнесом. В XXI-му столітті прискорення темпів змін в бізнесі, економіці та суспільстві в сфері управління персоналом ставлять завдання виробити нові правила для керівництва, організації, мотивації, управління і залучення персоналу. Провідні компанії світу сьогодні стикаються з радикальними змінами щодо організації робочої сили, робочого місця та світу праці взагалі. Ці зрушення змінюють правила майже для всіх напрямків управління людськими ресурсами. Керівники бізнесу і менеджери 3 персоналу більше не можуть продовжувати працювати за старими формами і методами, звичками і принципами. Тепер вони повинні освоювати нові способи думати про саму компанію, про ії персонал, його можливості та їх реалізацію. Провідні фахівці світу в галузі управління персоналом розробили « новий набір правил», що покликаний допомогти керівникам та HR-менеджерам розібратися в сучасних тенденціях. Ці правила відображають зрушення в мисленні і поведінці, які, на їх думку, необхідні, щоб керувати, організовувати, мотивувати і залучати до роботи співробітників

Робота в складі успішного колективу може бути додатковим стимулом, що сприяє стабільній продуктивній роботі і задоволеності працею.

Управління персоналом грунтується на кадровій концепції підприємства, що $є$ поряд 3 виробничою, фінансово-економічною, науково-технічною, маркетинговою політикою елементом загальної концепції його розвитку.

Кадрова політика на нашу думку, повинна будуватися на наступних принципах:

- повна довіра до працівника і надання йому максимальної самостійності;

• у центрі економічного управління повинні бути не фінанси, а людина і його ініціатива;

- результат діяльності підприємства визначається ступенем згуртованості колективу;

• максимальне делегування функцій управління працівникам;

- необхідність розвитку мотивації працівників.

Сьогодні в промислових підприємствах в основу кадрової політики закладено три базових принципи: персонал-стратегія, кадрова логістика, кадрова компетенція. Ці принципи охоплюють усі аспекти кадрової діяльності: систему кадрового планування підприємства; методи i джерела задоволення кадрових потреб; систему оцінки і відбору кандидатів на заміщення вакантних посад; рішення проблем адаптації прийнятого на роботу персоналу; систему безперервного удосконалення кваліфікаційного рівня працівників концерну; атестацію керівників і фахівців; формування резерву; формування сприятливого морально-психологічного клімату в колективах підрозділів концерну, підвищення корпоративної культури.

У зв'язку з розробленими стратегічними концепціями управління персоналом пред'являються і нові вимоги до майбутніх менеджерів 3 персоналу, зокрема: цілеспрямованість, масштабність, комунікабельність, здатність аналізувати і вирішувати комплексні проблеми, синтезувати рішення в умовах невизначеності і обмеженості інформації та ін. Головні напрямки кадрової політики промислових підприємств наведено на рисунку 1.

Механізм реалізації кадрової політики підприємства являє собою систему планів, норм і нормативів, організаційних, адміністративних, соціальних, економічних i інших заходів, спрямованих на рішення кадрових проблем і задоволення потреб підприємства в персоналі. 


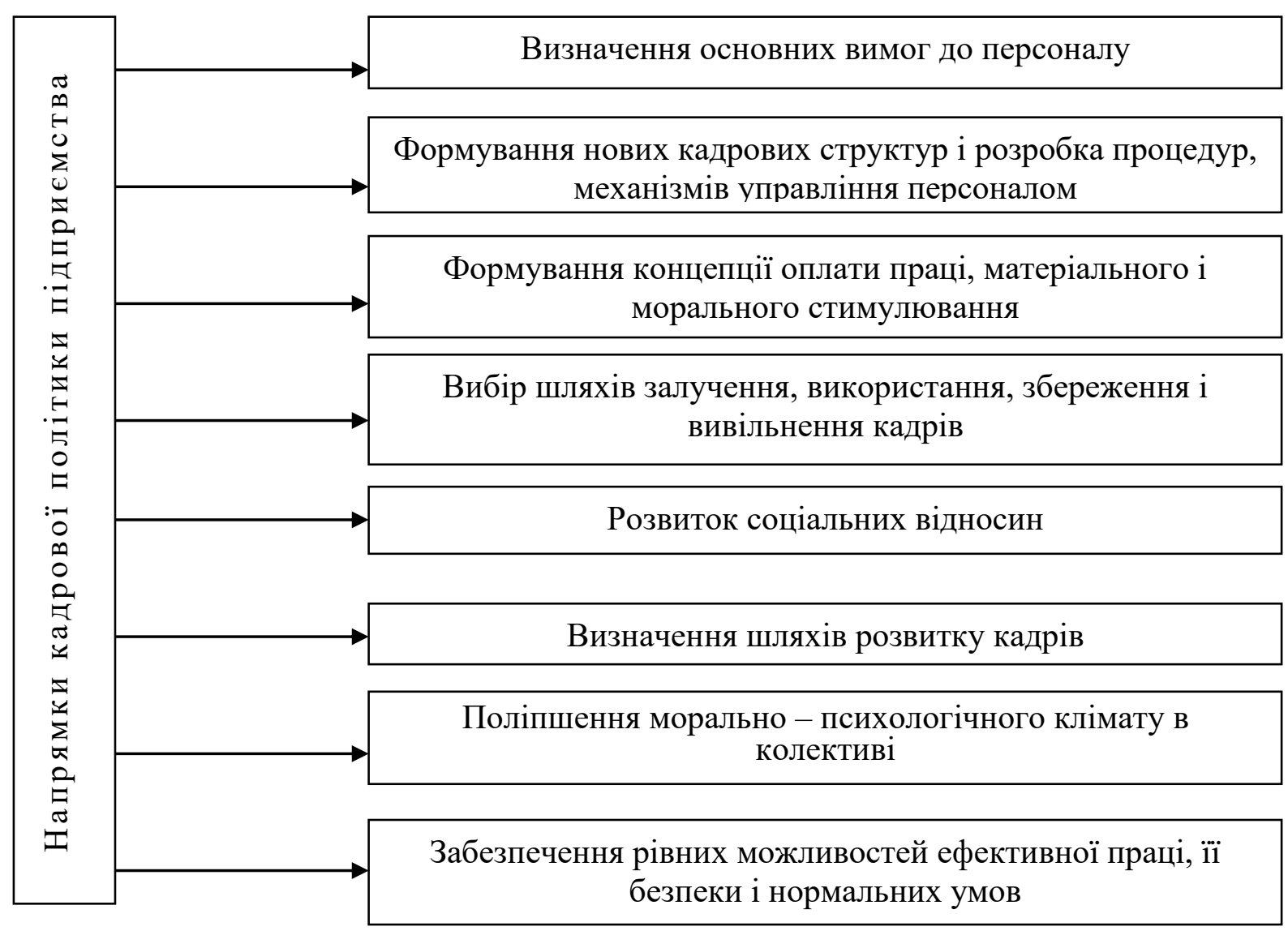

Рис. 1. Напрямки кадрової політики в промислових підприємствах

Головною особливістю всієї системи розробки і реалізації ефективної кадрової політики на підприємстві $є$ та обставина, що значну частку роботи з персоналом повинні виконувати самі лінійні керівники, а працівники кадрової служби зобов'язані допомагати їм у цьому і забезпечувати відповідну підтримку (витрати робочого часу лінійних керівників на виконання кадрових функцій у прогресивних підприємствах складають від 30 до $60 \%$ ).

У практиці управління персоналом в останні роки чітко просліджується переплітання різних його моделей: американської, японської і західноєвропейської. В цьому проявляється процес інтернаціоналізації сучасного менеджменту. Важливим етапом цього процесу стали асиміляція ідей системного підходу, розробка різних моделей організації, як системи - не тільки функціонуючої, але й такої, що розвивається, на основі яких сформувався новий підхід у кадровому менеджменті управлінні людськими ресурсами.

Основу концепції управління персоналом підприємства в даний час складає зростаюча роль особистості працівника, знання його мотиваційних установок, вміння їх формувати і направляти у відповідності із завданнями, що стоять перед підприємством.

Зміна економічної і політичної систем України в 90-ті роки одночасно надали великі можливості і містять серйозні загрози для існування кожної особистості, вносять значний рівень невизначеності в життя практично кожної людини.

Управління персоналом в такій ситуації набуває особливого значення, оскільки дозволяє реалізувати, узагальнити широкий спектр питань адаптації індивіда до зовнішніх умов, врахування особистісного фактора при побудові системи управління персоналом.

Виходячи на вітчизняний та світовий товарний ринки керівники підприємств стикаються 3 непристосованістю досвіду роботи 3 кадрами при плановій економіці до нових умов господарювання. Не зважаючи на такі позитивні аспекти, як гарантованість зайнятості, соціальний захист працівників, в радянській системі кадрового менеджменту були такі негативні аспекти як: 
1.Відсутність системи добору працівників (існував централізований розподіл випускників навчальних закладів).

2. Прийняття на керівні посади за партійною ознакою.

3. Відсутність системи мотивації і стимулювання ефективної роботи (через існування систему перерозподілу результатів праці як в середині підприємства, так і в державі в цілому) [4].

Менеджмент українських підприємств поставлено перед необхідністю реформування системи кадрового менеджменту загалом, необхідністю розробки філософії кадрового менеджменту своїх підприємств.

Укрупнено можна виділити три фактори, що впливають на працівників підприємства:

- ієрархічна структура підприємства - де основним засобом впливу є відношення владипідлеглості, примушення і контролю;

- культура, тобто шкала цінностей, вироблених суспільством, підприємством або групою осіб, соціальні норми, які регламентують дії особистості, примушують індивіда вести себе так, а не інакше без помітного тиску;

- ринок - мережа рівноправних відносин, що базуються на купівлі-продажу продукції і послуг, відношеннях власності, рівновазі інтересів продавця і покупця [7].

Характерною особливістю сучасних систем стимулювання на Заході є величезне поширення системи заохочення за впровадження різноманітних нововведень.

Так, більшість західноєвропейських фірм формують преміальні фонди за створення, освоєння й випуск нової продукції, але їхній розмір залежить від приросту обсягу продажу нової продукції, iї частки в загальному обсязі виробництва. Як правило, розумова праця оплачується вище, ніж фізична.

За даними спеціальних досліджень заробітна плата працівників розумової праці у середньому перевищує заробіток робітників: у Німеччині — на 20\%; Італії і Данії — на 22\%; Люксембурзі — на 44\%; Франції і Бельгії — на $61 \%$.

Середньо-тижнева заробітна плата американських інженерів майже у 2 рази більша за середню плату робітників.

У всіх країнах 3 розвинутою ринковою економікою спостерігається стала тенденція до індивідуалізації заробітної плати на підставі оцінки конкретних заслуг працівника.

Механізм індивідуалізації заробітної плати включає як диференціацію умов наймання, так і регулярну оцінку заслуг персоналу безпосередньо в процесі трудової діяльності. Наприклад, в США оцінюють особисті заслуги керівників і спеціалістів $80 \%$ компаній, а робітників - приблизно $50 \%$. У Франції індивідуалізована заробітна плата становить $3 / 4$ іiі приросту в керівників і спеціалістів, 2/3 у майстрів і майже $1 / 2-$ у робітників [3].

В усьому світі йде пошук найбільш раціональних моделей управління. Досвід багатьох фірм показав, що інвестиції в нове обладнання не приводять до підвищення продуктивності праці, якщо не враховується "людський фактор", тобто якщо одночасно не здійснюються великі вкладення капіталу в підготовку персоналу, створення резерву кадрів, у впровадження нових принципів організації праці. Для управлінського рівня необхідно, крім того, створення нової виробничої культури, що включає принципи групової роботи (виробничої діяльності), реорганізацію підготовки і підвищення кваліфікації персоналу з орієнтацією на системну, комплексну організацію роботи з резервом кадрів, на оплату праці виходячи з виробничих потреб, на стимулювання ініціативи і залучення в процес прийняття рішень, у тому числі спрямованих на підвищення якості обслуговування споживачів.

Отже, розглянемо американський та японський підхід до управління персоналом.

Американський - передбачає початкове визначення професійно-кваліфікаційної моделі „посади” i „підтягування” до найбільш відповідних працівників за схемою „посада-працівник”. Особливостями системи управління в американських фірмах є наступне: персонал розглядається як основне джерело підвищення ефективності виробництва; йому надається певна автономія; підбір здійснюється за такими критеріями, як освіта, практичний досвід роботи, психологічна сумісність, уміння працювати в колективі; орієнтація на вузьку спеціалізацію менеджерів, інженерів, вчених.

Американські менеджери традиційно орієнтовані на індивідуальні цінності і результати. Вся управлінська діяльність в американських компаніях грунтується на механізмі індивідуальної відповідності, оцінці індивідуальних результатів, розробки кількісних виражень цілей, які мають 
короткотерміновий характер. Управлінські рішення, як правило, приймають конкретні особи і несуть відповідальність за їх реалізацію [3].

Характерними умовами праці $є$ :

- зменшення обсягів роботи в центральних службах і скорочення адміністративного апарату;

- більш широкий перелік професій і посадових інструкцій;

- перехід на гнучкі форми оплати праці;

- об'єднання інженерів, вчених і виробничників у наскрізні колективи - проектно-цільові групи.

В американських фірмах застосовуються чотири форми залучення персоналу до управління:

1) участь працівників в управлінні працею та якістю продукції на рівні виробничого цеху чи іншого такого ж підрозділу;

2) створення робітничих рад або спільних комітетів робітників і менеджерів;

3) запровадження системи участі персоналу в одержаному прибутку;

4) участь представників найманої праці в роботі рад директорів корпорацій [4].

Зокрема, майже $25 \%$ американських фірм 3 кількістю працівників понад 500 осіб мають в організаційній структурі управління ради робітників чи спільні комітети робітників та адміністрації.

Американська практика в іiї найбільш сучасних і передовим з управлінської точки зору проявах розробляє і використовує широкий арсенал новітніх форм і методів роботи з резервом керівних кадрів. Вони тісно погоджуються з іншими елементами організації праці і управління, із системами оплати праці, у тому числі з диференційованим преміюванням.

Поряд 3 американськими системами, на яких базуються формування, розвиток і управління персоналом, а також організація роботи з резервом, зупинимося на японській практиці. Особливість функціонування японської системи полягає в тому, що вона створюється в рамках діючої структури і гнучкої системи групової відповідальності, горизонтальних зв'язків і стимулів функціонує в межах існуючих організаційних рамок .

Японська модель передбачає початкове вивчення сильних і слабких сторін особистості працівника і підбір для нього відповідного робочого місця (система „працівник - посада”).

Японській моделі характерна орієнтація на:

- довгу перспективу роботи на одному підприємстві;

- якість освіти й особистий потенціал робітника;

- оплата праці визначається комплексно, з врахуванням віку, стажу роботи, освіти та здібностей до виконання поставленого завдання;

- участь працівників у профспілках, що створюються в межах організації, а не галузі Основна причина успіхів японської економіки криється в методах управління. Використовуються головним чином дві групи методів: "канбан" ("точно вчасно") і "комплексне управління якістю" ("нуль дефектів"), відповідно до яких і будується робота з персоналом, ведуться його виховання, добір і формування резерву.

На відміну від методів, застосовуваних американськими фірмами (ефективні системи заробітної плати, аналіз організації праці і робочих місць, атестація службовців), японські корпорації в більшому ступені використовують відданість компанії, що служить. Досягається це шляхом ототожнення інтересів службовців 3 інтересами корпорацій, що створює здорову моральну обстановку в колективах і дозволяє підвищити ефективність їхньої роботи. Крім того, значне місце приділяється системі довічного наймання робітників та службовців, системі обліку виробничого стажу і зв'язаної з нею заробітній платі, активному спілкуванню і заохоченню часток і прямих зв'язків, просуванню і ротації кадрів, опору на навчання працівників. Ключовою ідеєю системи $\epsilon$ повага до людей.

У Японії і вищі посадові особи, і рядові виконавці вважають себе представниками корпорації. I ті й інші організаційні рішення (система пільг, премії при одержанні компанією великого прибутку, оплата більшої частини лікарняних витрат, продаж і здача в оренду житлових будинків працівникам по більш низькій ціні, позики на покупку житлових будинків по більш низькому відсотку, (близько 4-6\%) чим у комерційних банків) дозволяють, забезпечувати унікальний психологічний клімат на всіх рівнях великих ієрархічно організованих систем i, головне не допустити апатії i безвідповідальності. 
Японські корпорації часто проводять церемонії святкування відкриття нових виробництв, Нового року, відзначають дні народження службовців, що видаються рекорди, проводять спільні сніданки й обіди і т.п., організують спортивні зустрічі, групові туристичні поїздки, половину витрат на який оплачує компанія, заохочують неформальні зв'язки між керівниками і службовцями [8].

Своєрідною є система участі трудящих в управлінні виробництвом, що склалася в Німеччині. Вона включає: спільну участь у наглядових радах фірм представників капіталу й найманої праці; існування «робітника-директора»; виробничі ради на підприємствах, які складаються з робітників. Останні створюються на підприємствах, що мають не менше 5 постійних найманих працівників 3 правом голосу (вік-понад 18 років, стаж роботи-не менше 6 місяців). При цьому роботодавці зобов'язані надавати найманим працівникам і раді підприємства відповідну інформацію, приймати від них запити та пропозиції, вивчати й ураховувати думку ради підприємства 3 питань соціальноекономічного розвитку останнього [2].

Характерною особливістю сучасного виробництва за кордоном треба вважати перехід до різноманітних колективних (групових) форм організації праці, включаючи спільне виконання окремих завдань (контроль якості, обслуговування виробництва, навчання). 3-поміж різних форм групової роботи, спрямованої на підвищення ефективності виробництва та вдосконалення трудових відносин [5].

Передовсім варто назвати так звані гуртки якості, які, по суті, є неформальною організацією управління виробництвом, що співіснує паралельно 3 традиційною ієрархічною системою. За оцінкою західних спеціалістів, на кожний долар витрат на розвиток гуртків якості підприємства одержують 4-8 доларів прибутку. Тому невипадково 90\% найбільших фірм США використовують гуртки якості з метою підвищення ефективності виробництва, а в Японії функціонує понад один мільйон гуртків якості, які об'єднують майже 11 мільйонів працівників.

Ставиться задача забезпечення тісних робочих зв'язків між керівниками різного рівня в рамках фірми шляхом:

- широкої мережі консультативних і інших органів, що дозволяють вести підготовку і приймати рішення (за деякими оцінками, кожен керуючий у японській компанії бере участь у роботі $60-80$ формальних і неформальних робочих груп, що тісно співпрацюють між собою);

- спеціально розробленої і постійно діючої системи переміщення керівників на різні посади усередині фірми для вироблення в них універсалізму;

- постійного процесу підвищення кваліфікації кадрів у рамках різних семінарів, робочих груп і т.П., у який включаються представники різних функціональних служб і рівнів управління [1].

Висновки. Ми вважаємо, що позитивними ознаками систем управління персоналом в різних країнах світу які необхідно адаптувати в промислових підприємствах є:

1. Горизонтальне управління і турбота про всі ресурси, акцент на формуванні команди;

2. Децентралізована кадрова функція реалізується на лінійному рівні управління;

3. Спеціалісти з персоналу надають підтримку лінійному менеджменту;

4. Планування людських ресурсів повністю інтегровано в корпоративне планування;

5. Ціль - суміщення наявних людських ресурсів, кваліфікації і потенціалів із стратегією і цілями компанії;

6. Цільна корпоративна культура і балансування поточних потреб інтегрованої організації 3 зовнішнім середовищем [10].

Узагальнюючи досвід зарубіжних підприємств можна сформувати головну ціль системи управління персоналом: забезпечення кадрами, їх ефективне використання, професійний i соціальний розвиток.

В Європі та США чітко визначені службові обов'язки інженера, техніка і робітника. Представлені вище моделі мають як „плюси”, так і „мінуси”. Тому у світовій практиці намітилась тенденція застосування змішаної системи управління людськими ресурсами.

Отже для того, щоб створити дієву систему менеджменту на підприємстві, розробити власну фірмову філософію управління персоналом, слід виходити з досвіду провідних світових компаній, а крім того накопичувати власний досвід роботи з українськими працівниками. 


\section{Джерела та література}

1. Дементьева Т. А. Методы оценки уровня инновационного потенциала персонала на промышленных предприятиях . Економіка промисловості. 2009. № 3. С. 125-132.

2. Москаленко В.О. Критерії ефективного формування кадрового потенціалу. Національне господарство України: теорія та практика управління. 2008. С. 161-166.

3. Семчук Ж. В. Діагностика процесу управління персоналом машинобудівного підприємства в умовах ризику . Національне господарство України: теорія та практика управління. 2009. С. 115-123.

4. Гриньова В. М., Мажник Л. О. Технологія аналізу персоналу промислових підприємств на основі кластеризації. Економіка та право. 2009. № 2. С. 83-87.

5. D. Voronkov, A. Grynyov Strategic integration of the enterprises: conceptual model based on knowledge of the personnel. Економічний вісник Донбасу. 2010. № 4(22). С. 188-190.

6. Костін Ю. Д., Ущаповський К. В. Модель оцінки ефективності праці персоналу на енергетичних підприємствах. Економіка промисловості. 2010. № 3. С. 107-109.

7. Стахів О. Проведення оцінки персоналу на підприємстві з метою стимулювання працівників до підвищення кваліфікації. Україна: аспекти праці. 2007. № 1. С. 29-35

8. Слісєєва О. К., Третьяк О. О., Узунов В. В. Методологія управління персоналом: статистичні методи та моделі: монографія. Дніпропетровськ: «ІМА-прес», 2006.- 188c.

9. Воронков О. Г., Чепелев А.Т. Оценка уровня качества работы на промышленном предприятии./ О.Г. Воронков, А.Т. Чепелев - К.: Техника, 1989.

10. Писаревська Т.А. Інформаційні системи в управлінні трудовими ресурсами. / Т.А. Писаревька - К.: Пріор, 1997.

\section{References}

1. Dement`eva T. A. (2009). Metodы ocenky` urovnya y`nnovacy`onnogo potency`ala personala na promыshlennых predpry`yaty`yax [Methods of assessment of level of innovative potential of personnel at the industrial enterprises.]. Ekonomika promy`slovosti.- Industrial economy 3, 125-132. [in Russian].

2. Moskalenko V. O. (2008). Kry`teriyi efekty`vnogo formuvannya kadrovogo potencialu. [criteria of effective formation of personnel potential]. Nacional`ne gospodarstvo Ukrayiny`: teoriya ta prakty ka upravlinnya - National economy of Ukraine: Theory and practice of management. 161-166. [in Ukrainian].

3. Semchuk Zh. V. (2009) Diagnosty`ka procesu upravlinnya personalom mashy`nobudivnogo pidpry`yemstva $\mathrm{v}$ umovax ry`zy`ku [Diagnostics of management of personnel of machine-building enterprise in the conditions of risk.]. Nacional ne gospodarstvo Ukrayiny`: teoriya ta prakty ka upravlinnya. - National economy of Ukraine: Theory and practice of management. 115-123. [in Ukrainian].

4. Gry`n`ova V. M., Mazhny`k L. O. (2009) Texnologiya analizu personalu promy`slovy`x pidpry`yemstv na osnovi klastery zaciyi. [Technology of the analysis of personnel of the industrial enterprises on the basis of a clustering]. Ekonomika ta pravo - Economy and right. 2. 83-87. [in Ukrainian].

5. Voronkov D., Grynyov A. (2010) Strategic integration of the enterprises: conceptual model based on knowledge of the personnel. [Strategic integration of the enterprises: conceptual model based on knowledge of the personnel.] Ekonomichny j visny`k Donbasu - Economic bulletin of Donbass. 4(22). 188-190. [in Ukrainian].

6. Kostin Yu. D., Ushhapovs`ky`j K. V. (2010) Model`ocinky`efekty`vnosti praci personalu na energety`chny`x pidpry yemstvax. [Model of assessment of efficiency of work of personnel at the power enterprises]. Ekonomika promy`slovosti - Industrial economy. 3. 107-109. [in Ukrainian].

7. Staxiv O. (2007) Provedennya ocinky` personalu na pidpry`yemstvi z metoyu sty`mulyuvannya pracivny`kiv do pidvy`shhennya kvalifikaciyi. [Evaluating personnel at the enterprise for the purpose of stimulation of workers to professional development.] Ukrayina: aspekty` praci - Ukraine: aspects of work., 1, p.p.29-35 [in Ukrainian].

8. Yelisyeyeva O. K., Tret yak O. O., Uzunov V. V. (2006) Metodologiya upravlinnya personalom: staty ‘sty ‘chni metody ta modeli: monografiya. Dnipropetrovs $k$ : [Human resource management methodology: statistical methods and models: Monograph. Dnipropetrovsk] «IMA-pres». [in Ukrainian].

9. Voronkov O. G., Chepelev A.T. (1989) Ocenka urovnya kachestva raboty na promyshlennom predpry yaty y [Assessment of level of quality of work at the industrial enterprise] K.: Texny `ka,. [in Russian].

10. Py`sarevs`ka T. A. (1997) Informacijni sy`stemy`v upravlinni trudovy`my` resursamy`. [Information systems in human resource management]. K.: Prior [in Ukrainian]. 